«Keruen» scientific journal

M.O.Auezov Institute of Literature and Art

ISSN 2078-8134

Volume 2, Number 67 (2020)

https://doi.org/10.53871/2078-8134.2020.2-02

IRSTI 18.07.23.

\author{
A.T. Yespenova \\ T.K. Zhurgenov Kazakh National Academy of Arts \\ PhD student \\ Almaty, Kazakhstan, \\ E-mail: aespenova@mail.ru
}

\title{
ARTISTIC FEATURES IN THE PAINTER AMAN MUKAZHANOV'S WORKS
}

\begin{abstract}
The article studies the handicraft made of leather in the works of Aman Mukazhanov. Images in the work are analyzed, the painter's creativity is studied. At the same time, the level of development of modern leather arts is determined based on creativity of D. Shokparov, who contributed to the development of decorative and applied arts the trends in the development of leather working art are examined $\omega$ the article at the works of other modern artists through the art of Mukazhanov. The author also considers new trends of leather working art and master painters in this field. By carrying out comparative and stylistic analysis, he opens artistic peculiarity of the work. The historical and comparative methods make an effort to define the connection ofaims of art history theory and artistic process. From the article, we can learn the history and level of development and cunent state of the leather working art, which is one field of Applied and Decorative Ants.
\end{abstract}

Key word: artist, composition, fine arts, craft, leather art, craftsman.

Introduction. It is all known that professional and creative sprouts began to blossom in the field of Kazakh people's art stitchcraft. There is a good saying among the Kazakh peOple like "Unity is the strength". The thing done by the master gives a specific spiritual pleasure, elates and gladdens not one, but all. D. Shokparov and Z. Umbetov were the first among artists of Kazakh decorative arts, who worked with leather. The first works in their art were male and female belts, packsaddle, horse harnesses, leather bottle for kumis, and other attributes of nomadic culture. By analyzing historical worldview in own works and looking from modern perspective, they could not only save nationalpeculiarities but also did not forget about the meaning of field of use and graceful entireness. Nowadays artists always look for new forms of ornaments and patterns, new composition structureand own methodology. Making one product, they added various materials to it, thus worked with mixed technique. As a result, the formation of versatile and capable artists who remade the simple things used in everyday life in a contemporary style, making them more beautiful, is a pleasing event. Speaking of the leather working art the name of DarkembayShokparov fll'St comes to mind. Indeed, hearing about Darkembay, all Kazakh people remember skilled craftsmen and jewelers and keep their ears Open. DarkembayShokparuly was an esteemed man, because he had collected ancient relics, kept them as the apple of an eye, brought to the present day and revived the Kazakh national crafts (Abazov R. and Rysymbetov E. 2015).

Shokparuly dealtwith writingasetof scientific and informative articles as well as books and educational and methodical manuals in periodical publications about folk decorative and applied art, its origin and the names and ethnography. He left behind not only crafts products, data on their production and features, as well as records of his observations of life, and we know that this is his contribution to the development of applied and decorative art and a great legacy for the Kazakh people (History of the Kazakh art, 2007). 
Kudaibergen Bolatbayev wrote: "In this regard, there is no exaggeration in saying that having reached the age of maturity, Darkembay Shokparuly found a way into the hearts of their audience. Atrue master is always unfading luminary, which leads to blessings, honor and reputation of his people. The biography of Darkembay Shokparov like the work done by his masterful hands and his very influential life is a historical phenomenon.

Although the master lived only a quarter of a century, it is definite that every conscious citizen giving a report to the people abuts the best ideas. I decided to start with the vitality of the art of Darkembay Shokparuly. In this regard, every human life is measured not only by his time but his moral life too. The legacy left over from our ancestors wears down whereas the art gets better. As a result, Darkembay Shokparuly, who has explored and learned Kazakh handicrafts from its roots, did not extinguish the flame of national art. The whole secret lies in his industriousness. Indeed, the work inevitably pushes and pulls. The master rushed instantly and came to update some types of our craits which slowly began to fade." (Art culture and the idea of independence, 2010: 86). Of course, it is obvious that people do not live forever. However, not everyone is able to leave behind an art that will never be forgotten. Of course, the art of Darkembay Shokpamly serves as an example for the young generation and attracts them to work. (Classical studies: Multivolume, 2012).

Methods. Nowadays, there are many masters, who continue the path of the great master and known with the features of form structure in the field of art. As an example to this, we can name the products ofAman Mukazhanov, who works in different genres and stands out with a peculiar signature. Any material caught in his handwhether it is metal, wood or leather will retain its natural beauty and will carry the meaning of the tradition in his own understanding.

The methodology of the study predicts a comprehensive set of conceptual coordination of theory and practice art. The methodology of structural and hermeneutic coordination, historical and comparative analysis and analysis of art are used during the study. The requirement of objective and volume study examines the compatibility from the point of view of aesthetics, philosophy and art.

Historical and comparative methods make an effort to define the connection of aims of art history theory and artistic process. In studying the technology systematic, logical, characteristic, chronological, typical studies and art studies are used, as well as stylistic and comparative analyzes are carried out.

Aman Mukazhanov, who is the member of the Union ofArtists of the Republic of Kazakhstan and Union of Designers was born in 1953 in the city of Semey, the artist had graduated with a degree in art metal from the faculty of decorative and applied art of Almaty State Institute of Theatre and Arts. We see that the master, deeply mastered the history and traditions, finds harmony in everything ornaments, signs, displays and color composition and displays each world in its own place. By following the traditions of Kazakh art, he proved to be quite fruitful in creating new plastic molds. In his works, there is a clear reflection of inherent author's signature. We can pay special attention to the round, twisted, rectangular and zigzag shapes that are found in the works of the author. We see that Mukazhanov skillfully combines bulk forms, made by decision of the plane, and pays great attention to textures. All works, which are combined from a variety of materials, look harmoniously with each other. For realization of his mind, the author uses a multi-colored enamel, gold plating, leather, wood, bones and stones to give his work expressiveness and integrity.

His works are not only decorative, abstractly interpretive, most of them formed a network composition, completely mastered the totem signs of animals and birds. This is not a rare event that a person becomes a hero of a small world, but occurs as past of a holistic phenomenon, and not as the protagonist. In some places, it harmonizes with the lines of rock engravings and simple lines in complex patterns give the meaning and generosity to his works and improves their quality.

In the artist's collection, there are many women jewelry made very nice. The author uses colored enamel and fine carved bone and surrounds them with semiprecious stones. In his works, he uses the ancient traditional methods and techniques as granulation and lace embossing.

Results. Mukazhanov's works are modern, but at the same time there is a hidden motive with a deep ideological component of archaic reflected images. Allowing the audience as if to open the secret value, the author managed to harmonize the structural complexity of the forms of symbols 
and multifaceted characters. Artist's work is a synthesis of sculpture, jewelry art and applied art. Kazakh applied art and its artistic features are studied at national schools of art since the day of its establishment in stages of formation and development of local art. This will further allow an active use of analytical description, referring to the general theoretical data. Nowadays, the traditional handcraft itself feels a rebirth, experiencing a different interpretation of the fine arts and decorative and applied arts. In this regard, the decorative and applied arts are reflected in the new version; including the contemporary application of leather working art will be studied in depth. Considering the traditional continuity and innovative features, a number of tests were carried out on the work of artists working in this direction. .

Despite the fact that he worked on different materials, the artist was able to show the Specific features of each product. Inparticular, leather products such as "Makhambet" (silver, leather, 1999), "Bird" (leather, copper, 2001), "Kelin" (installation, leather, metal, 1998), "Soldier" (silver, leather , 2001), Tamgaly "(brass, red brass, leather, 2001)," The Legend of the StePpe "(copper, leather, acrylic, 2001) and other works made of different leather reflect color specificity and delicate harmony between skin and metal.

In addition, he could develop a theme, iconic feature and integrity in the work. The author works in the field of line alts of drawing and painting, but retains a thin bond and the uniqueness of each genre. You may notice the freedom of expressing his thoughts and that he has mastered every material in depth The author portrayed the national values, traditions, Kazakh culture and history in any genre he worked at and any material he dealt with. We can see the tradition and history of our country in the works of the artist, made of leather. In general, brown color has a special place also in leather works of other authors. Dim gentle warm brown skin on leather shows the natural reality. Thus, silver and copper used in works find harmony. For example, in his work "Kelin" (F igure 1) the image of a girl with saukele, Kazakh national headdress, on her head and vast steppe displayed behind are drawn by pressing down on the leather. In e background mountain ranges and the image of the sun god ymbol are also visible. The Kazakh steppe and the beauty and tenderness of Kazakh girls are shown. The bride and her friends dress saukele on her head. The author has shown one of the ceremonies and traditional rites of the Kazakh people of great importance like marriage of daughter and son through his work An example of a national headdress saukele is illustrated in a special way. On its upper part it has a semi-circular tuii, which is called the "Crown". It was decorated with precious stones, gold, silver, pearls and was inlaid with gold thread. The author 1138 depicted saukele on girl's head with silver. In other words, Silver was sticked to the image depicted by pressing down the leather. The work, which is full of harmony, shows a single image.

Considering the human with its average being surrounding traditional way of life, he has subj ected to his own laws. Repeating in the space peculiar shape of a philosophical explanation, relating the past and mture of the people, domestic rituals, superstitions and symbolic signs are determined in accordance with the rhythm of time (Klanten R., Ehmann S., Galindo M., 2015).

The artist wanted to convey the image of the mother. The image of the bride or a girl, a mother, a beauty is an image of Umay Ana, which was in the belief of ancient Turkic peoples of the Great Steppe a continuer of generation, symbol of prosperity and well-being. Along with the Kazakhs in Umay Ana believed such people as Khakas, Kyrgyz, Altai, Tuva, Shores and Turkish. Data on this is preserved in the folklore samples on the monuments of Orkhon-Yenisey. Aiter the entry of Islam in the Kazakh steppe, name otKokTengri was widely used along with the name goddess Umaiana, who is guardian of the mother and the child. Although today this character has lost its significance, it had a great importance in the understanding of our ancestors. In general, Turkic beliefs are closely connected with the symbols of art and ornaments. This was noted in study of Toktabaev 82 "The characters in the ornamentation of the Kazakhs and the Turkic peoples." (Valikhanov B., 2011: 9).

In the work of the author "Tamgaly Tas" written in 2001 (F igure 2), we see a clear picture of the stone complex of Tamgaly. The author in his work also painted one of the oldest monuments of the Zhetisu, a gallery of rock paintings Tamgaly another cultural heritage of our country. Petroglyphs depicted in the work are one of the most impoxtant monuments and diverse landscapes 
of Tamgaly. Rock art gallery was created by our ancestors in the Middle Bronze Age, Late Bronze Age, in the transitional period (early Saks), in the early Iron Age (Saks and Uisuns), medieval (early Turkic) and modern age (Dzhungars and Kazakhs) and in other historical periods. Petroglyphs, whichinclude series of the most impressive ancient rock paintings of Tamgaly, have aesthetic and cultural values of the Middle Bronze Age. Masters of Fine Arts at that time differed broad ideas, as a'recurring image of solar signs (solar-deity), clowns, soldiers with stone clubs, archers in wolf masks, fighters with weapons, scenes of sacrificing animals and humans, erotic scenes, the, young women while childbirth, as well as trucks, signs, symbols, bulls, horses, camels, wild boars, wolves and deers. Monument "Tamgalytas" is an integral part of the story, with deep content depicting important historical events.

The author placed copper in the middle of the painting, comparing the leather with an image of the Kazakh steppe, and copper is Tamgaly tas, part of that huge steppe. Lined up rectangular ccpper parts bring to mind various types of broad Steppes. The color and texture of the leather is very favorable for the display of nature, so the steppe is very clearly expressed. In ancient times, the petroglyphs in the culture were used as a tool to exchange messages. We can say that this is an indicator of people's achievement in self-development. Petroglyphs always reflect archaic, mythological scenes and movements of ancient people during some rituals. All of them remain in the history as semantic signs, the first traditional forms, the development of art (Krykbayeva S. and Kaldybayeva G., 2016: 60).

Discussion. Today, the author's work attracts many art lovers, and there are also young people who want to know about the artist's work. He shares his talent with young people, and wants to teach the creativity to them.

Currently, a lot of products are made of leather: paintings, dishes, bags and sacks, as well as jewelry and decoration. As an example of such work, we can mention artist N.Vshivtseva, who makes souvenirs, pendants and bracelets. She comes out her work by combining different stones with leather. In addition, there are other artists who work with the leather, including K.Ayypkaliyev who makes dishes out of the leather, B. Beysbekov and S. Bultrikovamake different panels of leather, M. Asanbayev makestrunks from leather, TBeginbet combines leather, wood and bone. Finally, N. E .Kaliyev makes leather shoes, and lb. Naushabayev also left a contribution to the number of leather products.

Umbetov Zhangir and Ihanova Amankul invented technology "lcushkon", which left an unchanged mark in the art of leather processing

Each of the artists in their works displayed their high level of professionalism, foresight and a wide range of interests. Basically, there should not be the verge between life and work of artists, as productive work is the key to life. For all of the artist things around the world, people and the nature are the phenomenon of the highest level, through them, they study all the elements of our world and its laws of unity and harmony.

Today, we see a wide range of new ideas of the artist, and the continuation of the big work. Each author has collected speciti Cpeculiarities and unique aspects of the art. Impressing realism, skill and, above all, a big bright light of the artists'soul interested all researchers ofart. During the development of technology and time of independence, artists are engaged in restoring forgotten antiques, and raising the level of art. We can say with confidence that this is a great contribution to the resumption of a new form of leather art and the development of culture and art of the country (Kabdiyeva S., 2002).

It is known that the Kazakh folk crafts has a long history. Unlike other countries that in the Kazakh national culture has a particular and deep philosophical meaning in tastes and Arts (Hudson J., 2007).

The history of traditional arts and crafts of the Kazakh people, appreciating sacred material and spiritual needs, is very deep. While investigation, we looked at historical monuments and saved crafts of the past, ancient drawings, writings and valuable materials of scientists and researchers, and thus investigated thedevelopment of national art crafts, including leather art (Faegre T., 1979). 
Conclusion. Art ot processing the leather takes an important plaeein the. History of our national culture. Many masters have worked hard completing national traditional art, so that everyone understocq this art. Many national products of the Kazakh people made by craftsmen at any time need to be studied in terms of art (Schoenauer N., 2003).

Each of the artists in their works displayed their high level of professionalism, foresight and a wide range of interests.Basically, there should not be the verge between life and work of artists, as productive work is the key to life. For all of the artist things around the world, people and the nature are the phenomenon of the highest level, through them, they study all the elements of our world and its laws of unity and harmonyAt present time, not all types of decorative art develop apace. Some of them have wide acceptance among artists and also are popular among the audience. These include tapestries, jewelry andbatik. There is a growing interest in the Kazakh equipment and devices. Such types of arts and crafts are placed in a prominent place on the shelves of exhibitions, and has a high demand inthe market (Highmore B., 2002).

This will normalize the state of the art industry. Since the ceramic or glass industry types require special process and production, it faced with the problem of development. However, it should be noted that there are masters who overcome the obstacles and even partially achieved good results. And though during this period the level of leather art hasincreased, but connection with the traditional art of our ancestors and their techniques for leather carewas wiped. Nowadays a lot of artists workwith ready-treated leather. Of course, there are generations who inheritedtechnologies from their ancestors, but the rest of people hardly know them. However, there are masters promotingtraditional artinherited from generation to generationandconveying them to the younger people. Today, we see a wide range of new ideas of the artist, and thecontinuation of the big work. Each author has collected specific peculiarities and unique aspects of the art. Impressing realismskill and, above all, a bi g bright light of the artists' soul interested all nesearchers ofaxt. In this regard, before investigating some of the works of specific authors, we decided to discuss the basis of the historical development of leather art.

\author{
А.Т. Еспенова \\ Т.Қ. Жүргенов атындағы Қазақ Ұлттық өнер академиясы \\ $\mathrm{PhD}$ докторант \\ Алматы, Қазақстан, \\ E-mail: aespenova@mail.ru
}

\title{
Суретші Аман Мұқажанов еңбектеріндегі көркемдік ерекшелік
}

Андатпа. Мақаланың авторы Аман Мұқажанов шығармашылығындағы теріден жасалған туындыларды қарастырады. Шығармадағы көркем образдар талдауға алынып, суретші шығармашылығы зерттеледі. Сонымен қатар сәндік-қолданбалы өнердің дамуына үлес қосқан Д.Шоқпаров шығармашылығы негізінде қазіргі тері өңдеу өнерінің даму деңгейі айқындалады. Мақалада Мұқажанов шығармашылығы арқылы қазіргі таңдағы басқа да суретшілер шығармашылығындағы тері өңдеу өнерінің даму тенденциялары қарастырылады. Тері өңдеу өнерінің жаңа бағыттары мен осы саладағы суретші шеберлерге де тоқталып өтеді, Салыстырмалы, стилистикалық талдаулар жүргізу арқылы туындының көркемдік ерекшелікгерін аша түседі. Тарихи салыстырмалы әдістер көркемөнерлік үдеріс пен өнертану теориясының міндеттерінің байланысын айқындауға күш салады. Мақаладан сәндік-қолданбалы өнердің бір саласы тері өңдеу өнерінің тарихын, даму деңгейін, қазіргі күйін білуге болады.

Кілт сөздер: суретші, шығарма, бейнелеу өнері, қолөнер, тері өңдеу өнері, шебер.

\section{А.Т. Еспенова}

Т.Қ. Жүргенов атындағы Қазақ Ұлттық өнер академиясы 


\author{
$\mathrm{PhD}$ докторант \\ Алматы, Қазақстан, \\ E-mail: aespenova@mail.ru
}

\title{
Художественная особенность работ художника Амана Мукажанова
}

\begin{abstract}
Аннотация. В статье рассматриваются изделия ручной работы из кожи по произведениям Амана Мукажанова. Анализируются образы в работе, изучается творчество художника. В то же время уровень развития современного кожевенного искусства определяется на основе творчества Д. Шокпарова, внесшего вклад в развитие декоративноприкладного искусства. Рассматриваются тенденции развития искусства кожевничества. В статье представлены работы. других современных художников через искусство Мукажанова. Автор также рассматривает новые направления в искусстве кожевенного искусства и мастеров в этой области. Проводя сравнительно-стилистический анализ, раскрывает художественную особенность произведения. Исторические и сравнительные методы пытаются определить связь целей теории истории искусства и художественного процесса. Из статьи мы можем узнать историю и уровень развития и современное состояние искусства обработки кожи, который является одной из областей прикладных и декоративных искусств.

Ключевые слова: художник, произведение, изобразительное искусство, рукоделие, кожевенное искусство, мастер.

\section{Information about authors:}

A.T. Yespenova, T.K. Zhurgenov Kazakh National Academy of Arts, PhD student, Almaty, Kazakhstan, E-mail: aespenova@mail.ru
\end{abstract}

\section{REFERENCES}

[1]. Abazov R., Rysymbetov E. (2015). Media, Society, World: Social Theory and Digital Media Practice. Jurnalism of Mass Communication Quarterly, Vol. 92, Issue 2, 529-531.

[2]. Art culture and the idea of independence. (2010). Almaty: Signet Print. 271 p.

[3]. Classical studies: Multivolume. (2012). Almaty: Literature World. 392 p.

[4]. Faegre T. (1979). Tents: Architecture of the Nomads. Anchor Press/Doubleday: Anchor Books ed edition. 167 p.

[5]. Highmore B. (2002). The everyday life reader. London and New York: Routledge, 306 p.

[6]. Hudson J. (2007). Interior-Architecture Now. USA: Laurence King Publishers, 69p.

[7]. History of the Kazakh art. (2007). Almaty: Arda, 416 p.

[8]. Krykbayeva S., Kaldybayeva G. (2016). World outlook signs of traditional clothes in "World model" image. Central-Asian magazine about art science. 83-85.

[9]. Klanten R., Ehmann S., Galindo M. (2015). The New Nomads: Temporary Spaces and a Life on the Move. 256 p.

[10]. Kabdiyeva S., (2002). Contemporary art in Kazakhstan: problems and research. Almaty: Soros Kazakhstan Foundation. 248 p.

[11]. Schoenauer N. (2003). 6,000 Years of Housing (Revised and Expanded Edition). - W. W. Norton \& Company: Revised and Expanded edition. 504 p.

[12]. Valikhanov B. (2011). Historical and cultural monuments of Kazakhstan: Coll. Protection of historical and cultural monuments in kazakh society: Vol. 6, Almaty: Kazakhstan. 188 p.

\section{ӘДЕБИЕТ}

[1]. Абазов Р., Рысымбетов Е. (2015). Медиа, қоғам, әлем: сандық медианың әлеуметтік теориясы мен практикасы. Журналистік - коммуникацияға қатысушыларға, т.92, 2-шығарылым, 529-531.

[2]. Көркем мәдениет және Тәуелсіздік идеясы. (2010). Алматы: «Signet Print». 271 бет.

[3]. Классикалық зерттеулер: көп томды. (2012). Алматы: Әдебиет Әлемі. 392 бет.

[4]. Фариер Т. (1979). Шатырлар: көшпенділер сәулеті. «Якорь» Баспасөзі / баспа: кітаптары. 167 бет.

[5]. Хаймор Б. (2002). Күнделікті өмірдің оқырманы. Лондон және Нью-Йорк: «Routledge», 306 бет.

[6]. Хадис Дж. (2007). Қазіргі Интерьер-Сәулет. АҚШ: Лоуренс Кинг, 69 бет.

[7]. Қазақ өнерінің тарихы. (2007). Алматы: Арда, 416 бет.

[8]. Қырықбаева С., Қалдыбаева Г. (2016). «Әлем моделі» бейнесіндегі дәстүрлі киімнің дүниетанымдық белгілері. Орталық Азия өнертану журналы. 83-85 бет.

[9]. Клантен Р., Ехрам С., Галиондо М. (2015). Жаңа Көшпенділер: уақытша кеңістік және қозғалыстағы өмір. - 256 бет.

[10]. Қабдиева С. (2002). Қазақстандағы заманауи өнер: мәселелері мен зерттеулері. Алматы: Сорос қоры, Қазақстан. 248 бет.

[11]. Шенауэр Н. (2003). 6000 жыл тұрғын үй (қайта қаралған және кеңейтілген басылым). - 504 бет.

[12]. Уәлиханов Б. (2011). Қазақстанның тарихи және мәдени ескерткіштері: қазақ қоғамындағы тарихи және мәдени ескерткіштерді қорғау. 6, Алматы: Қазақстан. 188 бет. 


\section{ЛИТЕРАТУРА}

[1]. Абазов Р., Рысымбетов Е. (2015). Медиа, Общество, Мир: Социальная теория и практика цифровых медиа. - участникам коммуникации, т. 92, выпуск 2, 529-531.

[2]. Художественная культура и идея независимости. (2010). Алматы: Печать Печатью. $271 \mathrm{C.}$

[3]. Классические исследования: многотомный. (2012). Алматы: Мир Литературы. 392 С.

[4]. Фариер Т. (1979). Палатки: архитектура кочевников. Якорь пресс/издательстве: якорь книги издание Эд. 167 С.

[5]. Б. Хаймор (2002). Читатель повседневной жизни. Лондон и Нью-Йорк: Routledge, 306 p.

[6]. Хадсон Дж (2007). Интерьер-Архитектура Сейчас. США: Лоуренс Кинг, 69p.

[7]. История казахского искусства. (2007). Алматы: Арда, 416 с.

[8]. Крыкбаева С., Калдыбаева Г. (2016). Мировоззренческие признаки традиционной одежды в образе "модели мира". Центрально-Азиатский журнал об искусствоведении. 83-85.

[9]. Клантен Р., Ехрам С., Галиондо М. (2015). Новые кочевники: временные пространства и жизнь в движении. - 256 с.

[10]. Кабдиева С., (2002). Современное искусство в Казахстане: проблемы и исследования. Алматы: Фонд Сороса Казахстан.

$248 \mathrm{C}$.

[11]. Шенауэр Н. (2003). 6000 лет жилья (пересмотренное и расширенное издание). - 504 С.

[12]. Валиханов Б. (2011). Памятники истории и культуры Казахстана: сб. Охрана памятников истории и культуры в казахском обществе: вып. 6, Алматы: Казахстан. 188 C. 